\title{
Genetics of Leaf Rust Resistance in Canadian Spring Wheats AC Domain and AC Taber
}

J. Q. Liu and J. A. Kolmer, Agriculture and Agri-Food Canada, Cereal Research Centre, 195 Dafoe Road, Winnipeg, MB, Canada R3T 2M9

\begin{abstract}
Liu, J. Q., and Kolmer, J. A. 1997. Genetics of leaf rust resistance in Canadian spring wheats AC Domain and AC Taber. Plant Dis. 81:757-760.

The hard red spring wheat cultivar AC Domain and the Canada Prairie Spring wheat AC Taber have recently been licensed and released in western Canada and are resistant to leaf rust caused by Puccinia recondita f. sp. tritici. To determine the genetic basis of this resistance, the two cultivars were crossed with the leaf rust susceptible wheat Thatcher $(\mathrm{Tc})$, and $\mathrm{F}_{1}$ plants were backcrossed to Thatcher. $\mathrm{F}_{2}$ families from $\mathrm{Tc} * 2 / \mathrm{AC}$ Domain and $\mathrm{AC}$ Taber/Tc*2 were tested with isolates of $P$. recondita $\mathrm{f}$. sp. tritici as seedlings in the greenhouse and as adults in the field rust nursery. Segregation of $\mathrm{BC}_{1} \mathrm{~F}_{2}$ families indicated that $\mathrm{AC}$ Domain had seedling resistance genes Lr10 and Lr16, and the adult plant gene Lr34. AC Domain was also hypothesized to have the adult plant gene $L r 12$ based on infection types with $P$. recondita $\mathrm{f}$. sp. tritici isolates that differed for virulence to $\operatorname{Lr} 12$. The effective field leaf rust resistance of AC Domain was conditioned by $L r 16$ and $L r 34$. Segregation of $\mathrm{BC}_{1} \mathrm{~F}_{2}$ families and infection types of $\mathrm{BC}_{1} \mathrm{~F}_{3}$-derived $\mathrm{BC}_{1} \mathrm{~F}_{4}$ plants indicated that $\mathrm{AC}$ Taber had Lrl $4 a$ for seedling resistance, the adult plant gene Lr13, plus an additional uncharacterized adult plant resistance gene currently designated as $\operatorname{LrTb}$.
\end{abstract}

Additional keywords: specific resistance, Triticum aestivum

Leaf rust of wheat (Triticum aestivum L.), caused by Puccinia recondita Roberge ex Desmaz. f. sp. tritici Eriks \& E. Henn, is found in North America almost wherever wheat is grown $(8,15)$. Leaf rust resistant wheat cultivars for the eastern $\mathrm{Ca}$ nadian prairies of Manitoba and Saskatchewan have been released by the Agriculture and Agri-Food Canada Cereal Research Centre in Winnipeg since 1937, when the cultivar Renown with leaf rust gene $L r 14 a$ was released (6). Following the release of Renown, phenotypes of $P$. recondita f. sp. tritici with virulence to $L r 14 a$ were selected, and within 5 years the resistance conditioned by $\mathrm{Lr} 14 a$ was no longer effective (6). When other cultivars such as Lee (1950) with LrlO and Selkirk (1953) with Lr10, Lr14a, and Lrl6 followed, the resistance of $\mathrm{LrlO}$ and $\mathrm{LrlO}$ was also rendered ineffective by selective changes in the $P$. recondita $\mathrm{f}$. sp. tritici population (6). In 1965, the cultivar Manitou, with quality and agronomic characteristics of Thatcher and

Corresponding author: J. A. Kolmer

E-mail: jkolmer@em.agr.ca

Contribution No. 1687, Agriculture and Agri-Food Canada.

Accepted for publication 25 March 1997.

Publication no. D-1997-0502-04R

(C) 1997 Department of Agriculture and Agri-

Food, Government of Canada leaf rust resistance derived from Frontana, was licensed for release. Manitou was the first wheat released by the Cereal Research Centre that had the adult plant leaf rust resistance gene $\operatorname{Lrl3}$ (8). This gene is best expressed in the adult plant stage and cannot be detected in the seedling stage in greenhouse tests with $P$. recondita f. sp. tritici isolates from Canada. The Thatcher derivatives Neepawa (1969), Napayo (1972), and Katepwa (1982), all with Lr13, were the predominant wheat cultivars in the eastern prairie region from the late 1960s to the mid-1990s. Resistance conditioned by $\operatorname{Lrl3}$ was highly effective when first deployed in Manitou, but leaf rust phenotypes with virulence to $\operatorname{Lrl3}$ appeared within a few years. In the past few years, cultivars with $\mathrm{Lr} 13$ had high levels of leaf rust infection, although cultivars with this gene only were more resistant than susceptible cultivars such as Thatcher or Canthatch (10). The Neepawa backcross derivative Columbus has Lrl6 in addition to Lrl3, and has been highly resistant since its release in 1980. Other Neepawa derivatives with combinations of leaf rust genes were released by the Cereal Research Centre: Roblin (1986) with Lr1, Lr10, Lrl3, and Lr34; Pasqua (1990) with Lr11, Lr13, Lr14b, Lr30, and Lr34; AC Minto (1991) with $L r 11, L r 13$, and $L r 22 a$; and AC Cora (1994) with Lr13 and Lr21 (8). These cultivars with combinations of effective seedling and adult plant leaf rust genes have all been resistant since their release.
AC Domain, licensed for release in western Canada in 1993, is a leaf rust resistant, early-maturing, lodging resistant, high-quality bread wheat well adapted to Manitoba. AC Domain was selected from BW83/ND585 (BW83 = ND499/RL4137; ND585 = Butte*3//Waldron/RL4205). AC Domain is the first wheat cultivar released by the Cereal Research Centre since 1969 that has a diverse parentage and does not have Neepawa as a major component of its pedigree.

AC Taber is a Canada Prairie Spring (CPS) wheat, which was developed by the Semi-Arid Prairie wheat breeding project at the Agriculture and Agri-Food Canada Research Centre at Swift Current, Saskatchewan (5). AC Taber was selected from the cross of HY320*2/BW553 $($ HY320 = Tobari 66/Romany; BW553 = Red Bobs*2/PI 78383//8*Neepawa). AC Taber has a yield potential similar to Biggar (HY320) but has higher protein content and better milling quality. AC Taber also has better resistance to prevalent phenotypes of $P$. recondita $\mathrm{f}$. sp. tritici and common bunt (Tilletia caries) than does Biggar. The objective of this study was to determine the number and identity of leaf rust resistance genes in both AC Domain and AC Taber.

\section{MATERIALS AND METHODS}

AC Domain was used as the pollen parent and crossed with the leaf rust susceptible cultivar Thatcher $(\mathrm{Tc}) . \mathrm{F}_{1}$ plants were used as pollen parents and crossed with Tc. For the crosses with AC Taber, Thatcher was used as the pollen parent since AC Taber and other CPS wheats shed pollen poorly. Backcross $\mathrm{F}_{2} \quad\left(\mathrm{BC}_{1} \mathrm{~F}_{2}\right)$ families were evaluated for seedling resistance in the greenhouse with selected virulence phenotypes of $P$. recondita $\mathrm{f}$. sp. tritici (11). $\mathrm{BC}_{1} \mathrm{~F}_{2}$ families of both crosses, parents, and Thatcher backcross lines nearisogenic for wheat leaf rust resistance genes were seeded in clumps in fiber flats filled with a sand-peat-soil mix or in a greenhouse bed. Plants were grown at $20 \pm$ $2^{\circ} \mathrm{C}$ with $8 \mathrm{~h}$ of supplemental fluorescent light $\left(276 \mu \mathrm{E} \cdot \mathrm{m}^{-2} \cdot \mathrm{s}^{-1}\right)$ per day. Nine to 10 days after seeding, the primary leaves were inoculated by atomizing urediniospores suspended in Dustrol (Ciba-Giegy Canada Ltd., Mississauga, ON) light mineral oil. Inoculated plants were incubated at $100 \%$ $\mathrm{RH}$ for $16 \mathrm{~h}$ at $20^{\circ} \mathrm{C}$. Fifteen to 20 seedlings of each $\mathrm{BC}_{1} \mathrm{~F}_{2}$ family were tested 
with each isolate of $P$. recondita f. sp. tritici used. Infection types (IT) on primary leaves were rated 12 days after inoculation using a scale of 0 to 4 (11). Infection types 0 to $2^{+}$were considered resistant, and IT 3 to 4 were considered susceptible. The $\mathrm{BC}_{1} \mathrm{~F}_{2}$ families were classified as either segregating or homozygous susceptible. Goodness of fit to segregation ratios in $\mathrm{BC}_{1} \mathrm{~F}_{2}$ families from each cross was determined using chi-square tests (20).

To evaluate adult plant resistance, approximately 50 seeds of each $\mathrm{BC}_{1} \mathrm{~F}_{2}$ family were planted in 2-m rows in the 1995 field rust nursery. Susceptible spreader rows were inoculated with a mixture of $P$. recondita f. sp. tritici phenotypes (MBR, MDR, MFM, and TDG) prevalent in the eastern prairie regions of Canada in 1994 (9). AC Domain, AC Taber, Thatcher, and 41 near-isogenic Thatcher lines were also evaluated for leaf rust severity and response in the field nursery. Rust ratings were recorded in the early milk stage when the susceptible check Thatcher had a severity (13) and response (19) rating of 70 to $90 \%$ susceptible (70-90 S). To further determine the identity of the adult-plant resistance genes in AC Domain and AC Taber, single plants with different leaf rust resistant responses were selected from the $\mathrm{BC}_{1} \mathrm{~F}_{2}$ families which were homozygous susceptible in the seedling stage to all leaf rust phenotypes tested. The selected $\mathrm{BC}_{1} \mathrm{~F}_{2}$ plants with adult plant resistance were harvested individually, and $\mathrm{BC}_{1} \mathrm{~F}_{2: 3}$ plants were grown in the greenhouse. $\mathrm{BC}_{1} \mathrm{~F}_{3: 4}$ lines derived from single $\mathrm{BC}_{1} \mathrm{~F}_{2: 3}$ plants were evaluated for adult plant leaf rust resistance in the greenhouse and in the field. In the greenhouse test, flag and penultimate (F-1) leaves were inoculated with $P$. recondita f. sp. tritici phenotype $\mathrm{BBB}$, which is avirulent to adult plants with Lrl3, and with phenotype MBR, which is virulent to Lrl3. In the 1996 field rust nursery, $\mathrm{BC}_{1} \mathrm{~F}_{3: 4}$ lines with adult plant resistance derived from $\mathrm{Tc} * 2 / \mathrm{AC}$ Domain and $\mathrm{AC}$ Taber/Tc*2 were compared for leaf rust severity and response with Thatcher backcross lines RL4031 (TcLr13) and RL6058 (TcLr34).

\section{RESULTS}

AC Domain. AC Domain had a low IT of ; to ; 1 to all $P$. recondita $\mathrm{f}$. sp. tritici isolates listed in Table 1 that had low IT on RL6005 (TcLr16), and IT ;23 to phenotype CGB, which is virulent to TcLrl6. The Tc*2/AC Domain $\mathrm{F}_{2}$ families segregated to fit a two-gene ratio (3 segregating : 1 homozygous susceptible) when inoculated as seedlings with $P$. recondita $\mathrm{f}$. $\mathrm{sp}$. tritici phenotypes BBB and TBB, which are both avirulent to LrIO and Lrl6 (Table 2). When tested with phenotype SBD, which is virulent to $\operatorname{LrlO}$ and avirulent to $\operatorname{Lrl6}$, the same $\mathrm{BC}_{1} \mathrm{~F}_{2}$ families segregated to fit a single-gene ratio (1:1). Since the families that segregated with phenotype SBD also segregated with phenotypes $\mathrm{BBB}$ and $\mathrm{TBB}$, one of the two genes conferring resistance to $\mathrm{BBB}$ and $\mathrm{TBB}$ must also confer resistance to SBD. All $\mathrm{BC}_{1} \mathrm{~F}_{2}$ families were homozygous susceptible when tested with phenotype CGB, which is virulent to both $\mathrm{LrlO}$ and Lr16. These results indicated that AC Domain has two seedling genes for leaf rust resistance; one is $\operatorname{LrlO}$, which conditioned resistance to $\mathrm{BBB}$ and TBB, and the other is Lrl6, which conditioned resistance to phenotypes $\mathrm{BBB}$, TBB, and SBD.

The same $\mathrm{BC}_{1} \mathrm{~F}_{2}$ families segregated to fit a 3:1 ratio as adult plants in the field rust nursery, which indicated that AC Domain had two genes that conditioned field resistance to $P$. recondita $\mathrm{f}$. $\mathrm{sp}$. tritici. Of the two seedling resistance genes identified in this cultivar, only Lr16 conferred some resistance to $P$. recondita $\mathrm{f}$. $\mathrm{sp}$. tritici in the field. TcLrl6 had a leaf rust severity and response of $50 \%$ moderately resistant to moderately susceptible (50 MRMS) in the rust nursery (Table 1). RL6004 (TcLr10) had a leaf rust reaction of $70-90 \mathrm{~S}$, the same rating as Thatcher. All Tc*2/AC Domain $\mathrm{F}_{2}$ families that segregated for resistance to phenotype SBD also segregated for resistance as adults in the field rust nursery, which indicated that Lr16 conditioned effective field resistance. Of the Tc*2/AC Domain $F_{2}$ families that were homozygous susceptible to SBD as seedlings, 15 segregated for adult plant resistance in the rust nursery test, and 16 were homozygous susceptible. The 1:1 ratio indicated the presence of a single effective adult plant resistance gene in AC Domain. This adult plant resistance gene should be Lr34 since all $\mathrm{BC}_{1} \mathrm{~F}_{3: 4}$ lines derived from single $\mathrm{BC}_{1} \mathrm{~F}_{2}$ plant selections had field leaf rust reactions identical to those of TcLr34 (Table 3 ) and also showed leaf tip necrosis, a condition often associated with this gene (2). In the greenhouse tests, these lines produced an intermediate IT 23 to both phenotypes BBB and MBR, which was the same IT as for TcLr34.

Adult plants of AC Domain, Thatcher, RL6011 (TcLr12), TcLr16, and TcLr34 were tested with leaf rust isolates that produced IT $3^{+}$to TcLrl6 in the seedling stage. Adult plants of AC Domain had very low IT 0; and ; to isolates MJB 34-1 and MJB 76-2, which had very low IT ; and $; 1^{-}$ on adult plants of TcLr12 and had intermediate to high IT $2^{+} 3^{+}$on adult plants of TcLrl6 (Table 4). AC Domain had intermediate to high IT of $2^{+} 3^{+}$to isolate TJB 77-2, which had high IT $3^{+} 4$ on TcLrl2 and intermediate to high IT $2^{+} 3^{+}$on TcLrl6. Both AC Domain and TcLrl2 had intermediate IT $22^{-} \mathrm{c}$ when inoculated with isolate TJB 50-1 (Table 4). The adult plant IT indicated that AC Domain probably has Lr12 in addition to Lr34 for adult plant resistance. However, Lr12 did not confer effective field resistance in the $\mathrm{Tc} * 2 / \mathrm{AC}$ Domain $\mathrm{F}_{2}$ families, since TcLrl2 was as susceptible as Thatcher in the 1995 field test (Table 4).

AC Taber. AC Taber had seedling IT $; 12$ to $2^{+}$to all isolates tested except isolate TBJ, which produced IT ; (Table 1). When tested with isolate TBJ, which is avirulent to $L r 14 a$, the AC Taber/Tc*2 $\mathrm{F}_{2}$ families segregated to fit a $1: 1$ ratio, which indicated a single gene for resistance. The resistant plants in segregating $\mathrm{BC}_{1} \mathrm{~F}_{2}$ fami-

Table 1. Seedling infection types ${ }^{\mathrm{a}}$ and adult plant field reactions ${ }^{\mathrm{b}}$ to Puccinia recondita f. sp. tritici in wheat cultivars AC Domain, AC Taber, and Thatcher backcross lines near-isogenic for leaf rust resistance genes

\begin{tabular}{|c|c|c|c|c|c|c|c|c|}
\hline \multirow[b]{2}{*}{ Cultivar/Lr line } & \multicolumn{7}{|c|}{ P. recondita f. sp. tritici phenotype } & \multirow{2}{*}{$\begin{array}{l}\text { Field rust severity } \\
\text { and response }\end{array}$} \\
\hline & BBB & CGB & MFM & MBR & SBD & TBJ & TBB & \\
\hline AC Domain & $; 1$ & $; 23$ & $; 1$ & $; 1$ & $; 1$ & $; 1^{=}$ & ; & TR \\
\hline AC Taber & $; 122^{+}$ & $22^{+}$ & $22^{+}$ & $2^{+}$ & ;12 & & $; 2^{+}$ & TR \\
\hline Thatcher & $3^{+} 4$ & $3^{+} 4$ & $3^{+} 4$ & $3^{+} 4$ & $3^{+} 4$ & $3^{+} 4$ & $3^{+} 4$ & $70-90 \mathrm{~S}$ \\
\hline TcLr10 RL6004 & $; 1$ & $3^{+}$ & $33^{+}$ & $3+4$ & $3+4$ & $; 1$ & $; 11^{+}$ & $70-90 \mathrm{~S}$ \\
\hline TcLr13 RL4031 & $22^{+} 3 \mathrm{c}$ & $2+3 c$ & $233^{+}$ & $33^{+}$ & $2^{+} 33^{+}-$ & & $33^{+}$ & 50 MRMS \\
\hline TcLr14a RL6013 & $3^{+} 4$ & $3^{+} 4$ & $3+4$ & $3^{+4}$ & $; 1^{+}$ & $; 12^{-}$ & $3^{+} 4$ & $70-90 \mathrm{~S}$ \\
\hline TcLr16 RL6005 & $; 12^{-}$ & 3 & ;1 & 12 & $; 12^{-}$ & $2^{-}$ & $; 12$ & 50 MRMS \\
\hline TcLr34 RL6058 & $23^{+}$ & $; 23$ & $; 23^{+}$ & $33^{+}$ & $33 c$ & $\ldots$ & $23^{+}$ & $10 \mathrm{M}$ \\
\hline
\end{tabular}

${ }^{a}$ Infection types on primary leaves were rated 12 days after inoculation on a scale of 0 to 4 (11). The + and - symbols denote more or less sporulation, respectively; c indicates uredinia surrounded by chlorosis.

${ }^{\mathrm{b}}$ Field reactions to a mixture of P. recondita f. sp. tritici phenotypes in the 1995 field rust nursery. Percent rust severity ranging from TR (trace) to $100 \%$ on individual plants, with $\mathrm{R}=$ resistance (flecks and small uredinia with necrosis), $\mathrm{M}=$ mixed infections (small and moderate-sized uredinia), $\mathrm{MR}=$ moderately resistant (large necrotic flecks and large uredinia), MS = moderately susceptible (moderate to large uredinia with chlorosis), and $\mathrm{S}=$ susceptible (large uredinia). 
lies had IT identical to the Thatcher backcross line RL6013 (TcLr14a). All AC Taber/Tc*2 $\mathrm{F}_{2}$ families were homozygous susceptible when tested with phenotypes $\mathrm{BBB}$ and MFM, which are virulent to Lr14a (Table 2). The seedling segregation data indicated that AC Taber has Lr14a.

When challenged with a mixture of $P$. recondita $\mathrm{f}$. sp. tritici phenotypes in the field rust nursery, the AC Taber/Tc*2 $\mathrm{F}_{2}$ families segregated to fit a 3:1 ratio, which indicated that AC Taber had two effective genes for field leaf rust resistance. This resistance must be due to adult plant resistance genes, since line TcLrI4a had a leaf rust rating as high as Thatcher (70-90 S) (Table 1). The single gene line RL4031 ( $\mathrm{Tc} L r 13$ ) had a field leaf rust reaction of 40 to $60 \%$ moderately resistant to moderately susceptible with large necrotic flecks and moderate to large uredinia with chlorosis (40-60 MRMS) (Table 3). The same field leaf rust reaction was observed in $\mathrm{BC}_{1} \mathrm{~F}_{3: 4}$ line 409 , derived from a single $\mathrm{BC}_{1} \mathrm{~F}_{2}$ plant selection (Table 3 ). In the greenhouse tests of adult plants, this line had low IT ;12 to phenotype BBB and high IT $33^{+}$to MBR, which indicated that line 409 had Lr13. AC Taber also had a second gene that conditioned adult plant resistance. $\mathrm{BC}_{1} \mathrm{~F}_{3: 4}$ lines 381 and 412 had a field leaf rust reaction of flecks and small uredinia with chlorosis, which was distinct from the adult plant resistance conditioned by $\operatorname{Lr} 13$ or $\operatorname{Lr} 34$. In greenhouse adult plant tests, lines 381 and 412 had a high IT of $33^{+}$to leaf rust phenotype BBB and low IT of $; 1^{-}$to 2 to phenotype MBR (Table 3), which indicated that these lines lack Lrl3 but may have an uncharacterized adult plant gene for leaf rust resistance. The second adult plant resistance gene in AC Taber is temporarily designated as $\mathrm{LrTb}$.

\section{DISCUSSION}

It was determined that AC Domain had two genes for seedling resistance, $\operatorname{Lr} 10$ and Lr16, and probably two genes for adult plant resistance, $\operatorname{Lrl} 12$ and $\operatorname{Lr34}$. Lr10 was determined to be present in Butte and Waldron (12), which are in the pedigree of AC Domain. Lrl6 is present in a number of Canadian and U.S. hard red spring wheats and interacts with $\operatorname{Lrl} 3$ and $L r 34$ for improved levels of resistance $(4,16)$. Lrl2 is present in Exchange (3), which is in the background of AC Domain, and is also in the Neepawa derivative Benito (J. A. Kolmer, unpublished). Lr34 may have been introduced into North American wheats from several different sources, as this gene has been found in many wheats worldwide $(1,2,14) . \operatorname{Lr} 34$ is currently one of the most important genes for leaf rust resistance in the Canadian and U.S. spring wheats (8).

AC Domain and TcLr34 had an intermediate-high IT $; 23$ to isolate $\mathrm{CGB}$ in the seedling tests; however, the $\mathrm{BC}_{1} \mathrm{~F}_{2}$ families derived from AC Domain all had high IT $3^{+} 4$ to phenotype $\mathrm{CBG}$. The small amount of seedling resistance previously shown by Lr34 to phenotype CGB was not reliably expressed in the $\mathrm{BC}_{1} \mathrm{~F}_{2}$ families.

Of the four genes identified in AC Domain, only Lr16 and Lr34 contributed significantly to effective leaf rust field resistance in the $\mathrm{BC}_{1} \mathrm{~F}_{2}$ families (8). The $P$.

recondita f. sp. tritici population in Manitoba has high frequencies of phenotypes with virulence to genes $\operatorname{Lrll}$ and $\operatorname{Lr} 12$, such that these genes no longer condition effective resistance. AC Domain is the first wheat cultivar released by the Cereal Research Centre since Manitou in 1965 that

Table 2. Segregation for resistance to Puccinia recondita f. sp. tritici in the greenhouse and field rust nursery in backcross $\mathrm{F}_{2}$ families of Thatcher*2/AC Domain and AC Taber/Thatcher*2

\begin{tabular}{|c|c|c|c|c|c|}
\hline \multirow[b]{2}{*}{ Phenotype } & \multirow[b]{2}{*}{ Gene detected } & \multicolumn{2}{|c|}{ Number of families ${ }^{a}$} & \multirow[b]{2}{*}{ Ratio } & \multirow[b]{2}{*}{$P^{\mathbf{b}}$} \\
\hline & & Seg. & Susc. & & \\
\hline \multicolumn{6}{|c|}{ Thatcher*2/AC Domain } \\
\hline $\mathrm{BBB}, \mathrm{TBB}$ & Lr10, Lr16 & 53 & 20 & $3: 1$ & 0.75 to 0.50 \\
\hline SBD & Lr16 & 42 & 31 & $1: 1$ & 0.50 to 0.25 \\
\hline CGB & $\ldots$ & 0 & 73 & $1: 1$ & $<0.001$ \\
\hline Field $^{c}$ & Lr16, Lr34 & 57 & 16 & $3: 1$ & 0.75 to 0.50 \\
\hline \multicolumn{6}{|c|}{ AC Taber/Thatcher*2 } \\
\hline TBJ & $\operatorname{Lr} 14 a$ & 38 & 29 & $1: 1$ & 0.50 to 0.25 \\
\hline BBB, MFM & & 0 & 67 & $1: 1$ & $<0.001$ \\
\hline Field $^{\mathrm{c}}$ & $L r 13, \operatorname{LrTb}$ & 54 & 23 & $3: 1$ & 0.25 to 0.10 \\
\hline
\end{tabular}

${ }^{\mathrm{a}}$ Seg. $=$ segregating for resistant and susceptible plants; susc. $=$ homozygous susceptible.

${ }^{\mathrm{b}} P=$ probability of $x^{2}$ value.

${ }^{c}$ A mixture of $P$. recondita $\mathrm{f}$. sp. tritici phenotypes was used to initiate a rust epidemic (9).

Table 3. Adult plant greenhouse infection types ${ }^{\mathrm{a}}$ and field reactions ${ }^{\mathrm{b}}$ to Puccinia recondita $\mathrm{f}$. sp. tritici in $\mathrm{BCF}_{4}$ lines selected from Thatcher*2/AC Domain and AC Taber/Thatcher*2, and Thatcher backcross lines near-isogenic for leaf rust resistance genes

\begin{tabular}{lcccc}
\hline & & \multicolumn{2}{c}{ Phenotype } & \multirow{2}{*}{$\begin{array}{c}\text { Field rust severity } \\
\text { and response }\end{array}$} \\
\cline { 3 - 4 } Line & Gene detected & BBB & MBR & \\
\cline { 3 - 4 } $\begin{array}{l}\text { Thatcher*2/AC Domain } \\
\text { Line 173 }\end{array}$ & Lr34 & 23 & 23 & $10-20 \mathrm{M}$ \\
Line 182 & Lr34 & 23 & 23 & $5-20 \mathrm{M}$ \\
AC Taber/Thatcher*2 & & & & \\
Line 409 & Lr13 & $; 12$ & $33^{+}$ & $40-60 \mathrm{MRMS}$ \\
Line 381 & LrTb & $33^{+}$ & 12 & $10 \mathrm{R}$ \\
Line 412 & LrTb & $33^{+}$ & 12 & $30 \mathrm{R}$ \\
Thatcher & & $3^{+} 4$ & $3^{+} 4$ & $90 \mathrm{~S}$ \\
TcLr13 RL4031 & $; 1$ & $3^{+} 4$ & $40-60 \mathrm{MRMS}$ \\
TcLr16 RL6005 & & $\ldots$ & $\ldots$ & $40 \mathrm{MS}$ \\
TcLr34 RL6058 & & $; 12$ & $; 23$ & $10 \mathrm{M}$ \\
\hline
\end{tabular}

${ }^{a}$ Infection types on flag and F-1 leaves were rated 12 to 14 days after inoculation on a scale of 0 to 4 (11). The + and - symbols denote more or less sporulation, respectively.

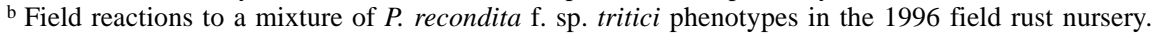
Percent rust severity ranging from TR (trace) to $100 \%$ on individual plants, with $\mathrm{R}=$ resistance (flecks and small uredinia with necrosis), $\mathrm{M}=$ mixed infections (small and moderate-sized uredinia), MR = moderately resistant (large necrotic flecks and large uredinia), MS = moderately susceptible (moderate to large uredinia with chlorosis), and $\mathrm{S}=$ susceptible (large uredinia).

${ }^{c}$ The $\mathrm{BC}_{1} \mathrm{~F}_{3: 4}$ lines were derived from single $\mathrm{BC}_{1} \mathrm{~F}_{2}$ plant selections that were susceptible to phenotype SBD in the seedling test.

Table 4. Adult plant greenhouse infection types $\mathrm{s}^{\mathrm{a}}$ and field reactions $\mathrm{s}^{\mathrm{b}}$ to Puccinia recondita $\mathrm{f}$. $\mathrm{sp}$. tritici phenotypes of AC Domain, Thatcher, and Thatcher backcross lines near-isogenic for leaf rust resistance genes

\begin{tabular}{lccccc}
\hline & \multicolumn{4}{c}{ Phenotypes } & \multirow{2}{*}{$\begin{array}{c}\text { Field rust severity } \\
\text { and response }\end{array}$} \\
\cline { 2 - 5 } Cultivar/Lr line & TJB 50-1 & TJB 77-2 & MJB 34-1 & MJB 76-2 & TR \\
AC Domain & $22^{-} \mathrm{c}$ & $2^{+} 3^{+}$ & $;$ & $0 ;$ & $90 \mathrm{~S}$ \\
Thatcher & $3^{+}$ & 4 & 4 & $3^{+}$ & $90 \mathrm{~S}$ \\
TcLr12 RL6011 & $22^{+}$ & $3^{+} 4$ & $; 1^{-}$ & $;$ & $50 \mathrm{MS}$ \\
TcLr16 RL6005 & $22^{+}$ & $2^{+} 3^{+}$ & $2^{+} 3$ & $2^{+} 3^{+}$ & $10 \mathrm{M}$ \\
TcLr34 RL6058 & $22^{-}$ & 23 & $2^{-3}$ & 23 & \\
\hline
\end{tabular}

${ }^{a}$ Infection types on flag and F-1 leaves were rated 12 to 14 days after inoculation on a scale of 0 to 4 (11). The + and - symbols denote more or less sporulation, respectively.

${ }^{\mathrm{b}}$ Field reactions to a mixture of $P$. recondita f. sp. tritici phenotypes in the 1995 field rust nursery. Percent rust severity ranging from TR (trace) to $100 \%$ on individual plants, with $\mathrm{R}=$ resistance (flecks and small uredinia with necrosis), $\mathrm{M}=$ mixed infections (small and moderate-sized uredinia), $\mathrm{MR}=$ moderately resistant (large necrotic flecks and large uredinia), MS = moderately susceptible (moderate to large uredinia with chlorosis), and $\mathrm{S}=$ susceptible (large uredinia). 
does not have Lr13. Due to superior yield, desirable agronomic characteristics, and overall disease resistance, AC Domain may become a commonly used parent in western Canada wheat breeding programs.

AC Taber was determined to have $L r 14 a$ for seedling resistance and $\operatorname{Lrl3}$ and an additional uncharacterized gene $(L r T b)$ for adult plant resistance. As with other CPS wheat cultivars such as Biggar and Genesis (7), CIMMYT (International Maize and Wheat Improvement Centre, Mexico City, Mexico) lines are prominent in the background of AC Taber. Many spring wheats released by CIMMYT have LrI4a and Lr13 (17), and these two genes have also been identified in Biggar and Genesis (7). The effective field leaf rust resistance of $\mathrm{AC}$ Taber was conditioned by the adult plant genes $L r 13$ and $L r T b$, since $P$. recondita f. sp. tritici phenotypes prevalent in the eastern prairie regions of Canada are virulent to Lrl4a (9). Gene Lrl3 still conditions moderate field resistance to leaf rust, although lines with only this gene have medium- to large-sized uredinia mixed with necrosis in field rust nursery tests.

AC Taber/Tc*2 $\mathrm{F}_{3: 4}$ lines with $\mathrm{LrTb}$ singly had field rust reactions that were distinct from $\operatorname{Lr} 12, \operatorname{Lrl3}$, and $\operatorname{Lr} 34$, but appeared to be similar to an adult plant gene identified in Biggar (7). Since AC Taber and Biggar have a very similar genetic background (5), it is likely that $L r T b$ is the same uncharacterized gene in Biggar. Singh and Rajaram (18) also found that CIMMYT wheats had adult plant resistance genes other than Lr13 and Lr34. Line 412, which was homozygous for $L r T b$, will be crossed and backcrossed to Thatcher to confirm that a single adult plant gene is present, and intercrossed with TcLr12, TcLr13, and TcLr34 to confirm that the resistance is conditioned by a previously uncharacterized adult plant gene.

\section{ACKNOWLEDGMENTS}

We thank the Western Grain Research Foundation for supporting this research, P. L. Dyck for development of the Thatcher near-isogenic lines, and P. Seto-Goh for excellent technical assistance.

\section{LITERATURE CITED}

1. Dyck, P. L. 1977. Genetics of leaf rust reactions in three introductions of common wheat. Can. J. Genet. Cytol. 19:711-716.

2. Dyck, P. L. 1991. Genetics of adult-plant rust resistance in 'Chinese Spring' and 'Sturdy' wheats. Crop Sci. 24:309-311.

3. Dyck, P. L., Samborski, D. J., and Anderson, R. G. 1966. Inheritance of adult-plant leaf rust resistance derived from the common wheat varieties Exchange and Frontana. Can. J. Genet. Cytol. 8:665-671.

4. German, S. E., and Kolmer, J. A. 1992. Effect of gene $L r 34$ in the enhancement of resistance to leaf rust of wheat. Theor. Appl. Genet. 84:97-105.

5. Knox, R. E, DePauw, R. M., Morrison, R. J., McCaig, T. N., Clarke, J. M., and Mcleod, J. G. 1992. AC Taber red spring wheat. Can. J. Plant Sci. 72:1241-1245.

6. Kolmer, J. A. 1991. Evolution of distinct populations of Puccinia recondita f. sp. tritici in Canada. Phytopathology 81:316-322.

7. Kolmer, J. A. 1994. Genetics of leaf rust resistance in three western Canada spring wheats. Plant Dis. 78:600-602.

8. Kolmer, J. A. 1996. Genetics of resistance to wheat leaf rust. Annu. Rev. Phytopathol. 34:435-455.

9. Kolmer, J. A. 1996. Physiologic specialization of Puccinia recondita f. sp. tritici in Canada in 1994. Can. J. Plant Pathol.
18:300-302.

10. Kolmer, J. A., Dyck, P. L., and Roelfs, A. P. 1991. An appraisal of stem and leaf rust resistance in North American hard red spring wheats and the probability of multiple mutations to virulence in populations of cereal rust fungi. Phytopathology 81:237-239.

11. Long, D. L., and Kolmer, J. A. 1989. A North American system of nomenclature for $P u c$ cinia recondita f. sp. tritici. Phytopathology 79:525-529.

12. McVey, D. V. 1989. Verification of infectiontype data for identification of genes for resistance to leaf rust in some hard red spring wheat. Crop Sci. 29:304-307.

13. Peterson, R. F., Campbell, A. B., and Hannah, A. E. 1948. A diagrammatic scale for estimating rust intensity on leaves and stems of cereals. Can. J. Res. 26:Section C:496-500.

14. Roelfs, A. P. 1988. Resistance to leaf and stem rusts in wheat. Pages 10-22 in: Breeding Strategies for Resistance to the Rusts of Wheat. N. W. Simmonds and S. Rajaram, eds. CIMMYT, Mexico, D.F.

15. Samborski, D. J. 1985. Wheat leaf rust. Pages 39-59 in: The Cereal Rusts. Vol. 2. A. P. Roelfs and W. R. Bushnell, eds. Academic Press, Orlando, FL.

16. Samborski, D. J., and Dyck, P. L. 1982. Enhancement of resistance to Puccinia recondita by interactions of resistance genes in wheat Can. J. Plant Pathol. 4:152-156.

17. Singh, R. P., and Rajaram, S. 1991. Resistance to Puccinia recondita f. sp. tritici in 50 Mexican bread wheat cultivars. Crop Sci 31:1472-1479.

18. Singh, R. P., and Rajaram, S. 1992. Genetics of adult-plant resistance in Frontana and three CIMMYT wheats. Genome 35:24-31.

19. Stakman, E. C., Stewart, D. M., and Loegering, W. Q. 1962. Identification of physiologic races of Puccinia graminis var. tritici. U.S. Dep. Agric. Agric. Res. Serv. E 6/7(rev.). 53 pp.

20. Steel, R. D., and Torrie, J. H. 1980. Principles and Procedures of Statistics. Ed. 2. McGrawHill Book Co., New York. 